\title{
Regional development, agricultural policies, and environmental instability
}

\author{
Inna Č́belková ${ }^{1, *}$, Svetlana Kalyugina ${ }^{2}$ and Polina Shmygaleva ${ }^{2}$ \\ ${ }^{1}$ Department of Trade and Finance, Faculty of Economics and Management, Czech University of Life \\ Sciences Prague, Kamýcká 129, Prague 6, Prague, 16500 Czech Republic \\ ${ }^{2}$ North Caucasus Federal University, Pushkin str., 1, Stavropol, 355009, Russian Federation
}

\begin{abstract}
This article aims at showcasing and displaying how the agricultural policies might become the key factor in causing environmental instability. Using various examples from different regions and countries we show that as the demand for food is growing with the increasing population and the reduction of arable land, governments around the world are intensifying their agricultural policies. We argue that as some of these policies might be irresponsible and short-sighted, this approach often leads to the massive adverse effects such as massive agricultural pollution, droughts, famines, and degradation. In addition, we show that novel technologies (especially information and communication technologies (ICTs)) need to be used in agriculture in order to help combating global warming and climate change as well as tackling other environmental problems. All of these might help the relevant stakeholders and policymakers to shape up the principles and blueprints for the sustainable agriculture that would correspond the principles and provisions of the sustainable development and would follow the Sustainable Development Goals (SDG).
\end{abstract}

\section{Introduction}

Over the last few decades, many countries around the world have made significant progress in human development and in creating comprehensive rural infrastructure. There is now an urgent need to prioritise rural livelihoods and rural economies in order to accelerate economic development in rural areas $[1,2]$. Access to education, health care, public security, infrastructure and public health services should be increased in order to strengthen selfemployment, to promote democracy and to support continued commitment to the development of the rural economy and rural development [3].

In general terms, the problem for rural areas is that they suffer from a series of interdependent problems that might impede their respective local economies. In the same time, many governments around the world have been unable to transform their rural areas because of a lack of investment in infrastructure, education, health care, and public health services $[4,5]$. All of these suggest that it is not only an infrastructure that fails to promote the potentials of the rural economy and rural development. On the contrary, it should include

* Corresponding author: cabelkova@pef.czu.cz 
such factors as population distribution, while small micro-enterprises develop and small towns, villages and main roads fail [6].

Supporting rural jobs and businesses is an absolute priority which can be achieved by expanding broadband access to high-speed connections and improving public transport in rural areas. The government should implement projects to educate farmers about new technologies and help them establish a foothold in rural areas to develop agriculture. It should ensure that the national rural development plans they often commence and then have to follow, can be completed, and should increase investment in cultural education in rural areas and rebuild rural schools that have been blindly removed [7-9].

In addition, the promotion of rural vocational and technical talent through universities and vocational schools is also crucial. It is intended to make it easier for parts of the population to contribute to the development of new rural areas and to make them more affordable. To achieve village regeneration, we must reduce bottlenecks in talent and maintain the integration of urban and rural development. In order to achieve the rejuvenation of the village, it must maintain integration into urban-rural development [10]. In the course of implementing this strategy, it is necessary to promote the integration of the rural and rural economy and the development of cooperation between the town and the countryside. The decline of rural areas in recent decades has shifted to urban areas, leading to a decline in rural areas, which has been exacerbated in recent years by the increasing urbanization and urbanization in such countries as China (which has a state that is based on the principles of socialism) [11].

The development of cooperation between rural and urban economies in rural areas will not only achieve the objective of economic development and growth in any country, but will also improve the economic prospects of rural areas. It is a brand-new strategy to support the transformation and development of agriculture in rural areas and to accelerate the integration of urban and rural areas by using rural revitalisation as a vehicle. The implementation of the rural regeneration strategy is in line with the development goals for agriculture and small farmers set by the $19^{\text {th }}$ Congress of the Communist Party of the People's Republic of China that was held in October 2017 [12]. According to its conclusions, the important partners in the work for rural women in China were the accelerating progress through economic empowerment of rural women, the National Commission for Employment and Rural Development, the Ministry of Women's Affairs and Rural Development and the Council of State [13]. Such initiatives can commit the government to developing and implementing laws and policies that promote equality, opportunity and participation so that rural women can benefit from trade and finance and make a strong contribution to inclusive economic growth [14].

There is evidence that improved growth and development prospects in rural areas through the integration of rural and urban areas boost the growth of the rural economy and the creation of new jobs and livelihoods for rural populations [15]. To complement these strengths and promote economic diversification in these communities, effective rural economic development must build actively on existing assets, strengthen communities, and create longterm value by attracting arrange of investments. The natural environment is thus crucial to give rural dwellers a sense of heritage and quality of life, and to attract visitors to the county who enjoy the opportunity to experience the rolling hills, steep mountains and freshly picked produce [16]. Although the pressures of intrusive development are felt in all communities, there are strategies to retain rural sites to ensure that communities achieve effective economic development for residents while preserving their distinctive rural character. By providing income-oriented tourism activities to preserve the rural landscape, local communities can benefit from the benefits of tourism, such as the creation of new employment opportunities, tourist jobs and economic development opportunities [17]. 
Our article is structured as follows: Section 2 describes the role of the agricultural policies in the environmental instability and the links between those two. Section 3 sheds some light on the state agrarian polices and their impacts on the environmental issues. Section 4 describes the novel technological trends and technological innovations in agricultural activities. Finally, Section 5 concludes this article and highlights the key conclusions and relevant and important policy implications and outcomes.

\section{Agricultural policies and environmental instability}

The global decline in soil health has also encouraged governments to cultivate pristine ecosystems, which can exacerbate environmental problems in the long run. But when it comes to the growing unpredictability of climate change and its impact on the environment, some aspects are still in the hands of farmers [18]. However, the way farmers reduce agricultural uncertainties that can increase short-term yields actually makes growth conditions worse in the long term.

The introduction of environmentally friendly agricultural technology will help crops adapt to changing climatic conditions and ensure crops when unreliable rainfall occurs. Nearnatural agriculture technologies recognise the importance of creating and maintaining healthy soils and are integrated into a wide range of agricultural practices such as irrigation, crop rotation, irrigation systems, soil fertility monitoring and soil health monitoring. Some of the benefits of conservation agriculture technologies are the reduction of the workforce, the improvement of soil fertility and the increase in crop yields compared to the reduction of carbon dioxide in the atmosphere [19]. Countries and communities must conduct research based innovations that have been shown to address food insecurity and environmental sustainability. However, the measures and steps outlined above aim to address these problems while mitigating climate change, which could improve food security in communities around the world. Based on this knowledge the support of policies that strengthen policy and provide adequate resources and resources to address food insecurity challenges should be arranged. These measures include implementing the measures to improve international food security, mitigating the impact of global warming on food supply and environmental sustainability, and supporting the development of innovative approaches to enhance food safety and sustainability in the food supply chain [20].

This is necessary to facilitate the development of more efficient, sustainable and sustainable agricultural practices, to ensure local sovereignty in food production and to increase the sustainability of the food supply chain and the global food system as a whole. What constitutes ecological, social and economic sustainability is continuously evolving and influenced by current issues, perspectives and values [21].

Although the state is considered an agricultural powerhouse, agriculture is responsible for a decline in the gross domestic product in many countries and its share of global GDP. The group stresses that agriculture has been a major driver of climate change adaptation in developing countries. Investment in agriculture is not a panacea for all challenges, and a holistic approach is needed to combat climate change, biodiversity loss and poverty, and to develop sustainable agriculture and food systems [22]. Agricultural trade can help achieve the Sustainable Development Goals (SDG), because world trade is based on an open, rulesbased trading system. Although most of the association's member states are large food producers, they are still facing food insecurity and malnutrition and will not make progress until these challenges are addressed. For example, in the United States, the 2014 Bellmon Amendment, which was included in the Food Peace Act, requires United States agencies providing international food assistance to document and ensure that their food is nutritious [23]. The Food and Agriculture Organization (FAO) and the United Nations Development Programme (UNDP) have had to act in response to the increasing environmental degradation 
in poor food-producing countries. As the impact of climate change increases in scope and severity, the global food system is threatened with reduced agricultural production, food insecurity, and malnutrition [24]. The environmental problems of food producers that could contribute to food security and food insecurity in poor food are the reduced genetic diversity of plants and biodiversity loss, as well as the effects of deforestation and other environmental degradation. Recently, considerable attention and resources have been devoted to providing guidance on elements of the CSA.

\section{State agrarian policies}

Agrarian economics was first offered in Asia in the first half of the $20^{\text {th }}$ century, and today it has become a more inclusive discipline covering a wide range of economic, social, political, economic, and social issues [25]. While agricultural economics used to be focused on agricultural issues, agricultural economists now focus on various issues related to the economics of food consumption. Due to the long-standing emphasis on information quality, researchers in the field examine their attributes in a variety of ways, such as in data collection, as well as data analysis [26].

The field of agrarian economy can trace its roots back to the work of soil economy, and its role in optimizing the decisions of agricultural producers has grown in importance since the turn of the $20^{\text {th }}$ century. Agricultural economists have made intensive use of data analysis and research in the fields of agriculture and land management, as well as in agricultural policy. They have also made important contributions to agricultural policy, such as the development of public agricultural policy. Agricultural economics emerged by combining the theory of companies with marketing and organizational theory. It developed into a largely empirical branch of general economics in the $20^{\text {th }}$ century [27]. Agricultural economics, like other forms of economic theory, is an analytical and mathematical approach to describing the economy that explicitly takes into account the link between sectors. The input-output model was invented by Kantorovich and his student Leontief, developed in the United States and formed the basis for many of the modern models of agrarian economics, such as agricultural production theory. In particular, it is associated with the process of global industrial agricultural restructuring initiated in the 1970s, which promoted selected rural production processes [28]. Nowadays, the increasing importance of the input-output model for the development of agricultural economics is apparent. The model was used to analyse a wide range of issues, such as the impact of climate change on agricultural production and the role of agriculture in global economic development. Unpacking the class dynamics of contract agriculture allows us to understand the social outcomes of these programs in the context of state agricultural policy and their impact on agricultural development. This rather politically - but committed - consideration was set aside in the economic-oriented sciences due to their focus on the economic and social effects of the state's agricultural policy. Moreover, the intensity of a land-use pattern could only occur in the context of its physical environment. This concept is of great importance today because of the importance of land use patterns for climate change research. Attention was paid to the early work of geographers, whose work was subordinated to physical environment factors when they attempted to identify patterns of "land use." We can therefore say that as geographers we still make an important contribution to the organisation of village and farming studies in the context of the physical environment and its impact on land use patterns [29].

In various countries, ministries of agriculture worldwide are working on the development of a new model for the development of agricultural products, including grains. The government resolution was designed to provide a framework for research and development in agriculture and the management of land-use patterns in rural areas. The agricultural sector is reaching the food security of some countries and the social problems of the rural population 
are being solved. Nixon's agricultural policy lowered food prices as intended, but the supplydemand imbalance manifested itself as a long-term problem.

The expansion efforts of the $18^{\text {th }}$ and $19 \mathrm{~h}$ centuries led to Western migration, which led to agricultural prosperity in rural areas. The establishment of farmland provided food and work for America's rapidly growing population, allowing the urban economy to flourish and more people to live in the cities. But the abundance associated with the country's expansion remained insufficient to provide America with food for the home front and allied nations during World War II and the Great Depression. In 1832, the Supreme Court, under Chief Justice John Marshall, promoted tribal sovereignty, recognizing the Native American tribes as domestically dependent nations. The opinion of the Marshall Court overlooked the importance of further promoting agricultural growth, including the role of the state in the development of agricultural production and its role in food security and economic development. American agriculture in support of global markets and war needs, the success of expansion-based policies became increasingly apparent. High grain prices were sustained by exports, prompting the United States Department of Agriculture to call 1910-1914 the "golden age" of agriculture. Although most agricultural policies have been characterised by financial support for farmers, demographic change has dramatically changed them in the $20^{\text {th }}$ century. As technological innovation increased crop yields and international demand declined, policymakers limited production to regulate supply and demand. While farms flourished, the relationship between rural and urban markets encouraged the growth of American cities. In the 1920s, agricultural policy was geared towards territorial expansion, and today we have returned to expansion - to a policy of grassroots expansion [30].

In the same time, it seems that the state agrarian policies need to be well-balanced and sustainable. This is crucial in our age of the global climate change that might threaten the rural development and agriculture in many countries and whole regions and endanger millions of people worldwide depriving them of livestock.

\section{Technological innovations in agricultural activities}

In addition to improved seed and crop protection products, novel technologies allow farmers to increase their productivity and improve their ability to manage their farms by managing their farms [31]. Advances in agricultural technology are, however, crucial to promoting a more sustainable agricultural system through continuous improvement and reduced resource consumption. For agricultural systems to be able to use new technologies and practices, they must be considered as an ecosystem within an agricultural ecosystem [32].

For example, farmers can grow more crops with less input materials to achieve higher yields and consume less input materials. Integrating pest management (IPM) and improving local adaptation and variety performance through appropriate genetic techniques are crucial to ensuring the sustainability of future generations of farmers [33]. Ecologically based alternatives are being developed to monitor the impact of climate change on agricultural systems and their ecosystems. They reduce economic production costs, protect the environment, soil health and livelihoods of local farmers, and promote viable farming communities around the world. In recent years, the introduction of digital technologies and precision farming has changed the way farmers treat crops and manage fields. The use of data analysis and data science in agriculture contributes to the development of more efficient and sustainable agriculture. As a result, modern farms benefit significantly from an everevolving digital agriculture. One does not have to be an expert to see how technology is changing the concept of agriculture and making it more efficient and sustainable for farmers and the environment. Agriculture will no longer depend on the uniform use of water, fertilisers and pesticides throughout the field. Benefits include reducing greenhouse gas emissions, reducing negative impacts on the surrounding ecosystem and reducing the use of 
fossil fuels [34]. The report also states that farms and holdings must be managed in a completely different way. The future of agriculture will be used for a wide range of purposes, such as food production, agriculture, research and education, and food production. It will be necessary to ensure that the technology promotes the efficiency and sustainability of farmers. This will enable farms to be more efficient, productive and sustainable than at any time in history. Agricultural machinery will play a crucial role in meeting the growing demand for food in the future. What most people do not realise is that applying current practices would actually lead to a reduction in greenhouse gas emissions and an increase in food security in the future.

\section{Main conclusions}

All in all, our results show that the agricultural pollution is affecting the health and wellbeing of people, animals, the environment and the economy. In the last decades, the growth in productivity, also called vertical expansion, became associated with exploding yields and the reduction in food costs, is responsible for a massive increase in the use of pesticides, fertilizers, and other chemicals.

This growth is predetermined by the growing demand for food as the human population keeps increasing and the climate change raises the water level of the oceans and decreases the amount of dry land. But these instruments and the instruments that make them possible have also contributed to massive agricultural pollution. Progress in adopting agricultural technologies must therefore cover declines caused by external factors such as climate change, while taking into account the world's ever-growing population.

With the world population approaching the unprecedented number of 8 billion people, sustainable agriculture is at the heart of the agenda. Governments and international bodies attach greater importance to achieving a sustainable intensification of agriculture. To create more sustainable farms and practices, new technologies must increasingly be used to help farmers, farming families, and farming communities combat climate change and other environmental problems. New technologies are an important step that will enable current and future generations of farmers to grow more of their food without jeopardizing the needs of our planet.

\section{References}

1. K. Huang, K., M. Dallimer, L. Stringer, A. Zhang, T. Zhang, Sustainability, 13 (4), 2002 (2021)

2. S. Khoshnava, R. Rostami, R. Zin, D. Štreimikienè, A. Yousefpour, W. Strielkowski, A. Mardani, Sustaiability, 11 (17), 4615 (2019)

3. D. Giribabu, C. Mohapatra, C. Reddy, P. VV Prasada Rao, International Journal of Sustainable Development \& World Ecology, 26 (2), 113-128 (2019)

4. T. Gebre, B. Gebremedhin, Global ecology and conservation, 20, e00707 (2019)

5. K. Janda, G. Rausser, W. Strielkowski, Eastern European Countryside, 19 (1), 177-217 (2013)

6. Y. Li, H. Westlund, Y. Liu, Journal of Rural Studies, 68, 135-143 (2019)

7. J. Phillipson, P. Tiwasing, M. Gorton, S. Maioli, R. Newbery, R. Turner, Journal of Rural Studies, 68, 230-239 (2019)

8. J. Abrhám, Y. Bilan, A. Krauchenia, W. Strielkowski, Economic research-Ekonomska istraživanja, 28 (1), 773-787 (2015) 
9. N. Vercher, C. Barlagne, R. Hewitt, M. Nijnik, J. Esparcia, Sociologia Ruralis, 61 (1), 163-189 (2011)

10. J. Abrham, W. Strielkowski, M. Vošta, J. Šlajs, Agricultural Economics, 61 (10), 450 (2015)

11. Y. Wang, Sustainability, 11 (2), 542 (2019)

12. P. McMichael, The Journal of Peasant Studies, 47 (1), 116-154 (2020)

13. J. Yuan, Y. Lu, R. Ferrier, Z. Liu, H. Su, J. Meng, A. Jenkins, Environmental Development, 28, 101-110 (2018)

14. G. Hilson, R. Maconachie, Geoforum, 111, 125-141 (2020)

15. M. Ehrenberger, P. Koudelková, W. Strielkowski, Periodica Polytechnica Social and Management Sciences, 23(2), 73-83 (2015)

16. S. Gnych, S. Lawry, R. McLain, I. Monterroso, A. Adhikary, Forest Policy and Economics, 111, 102088 (2020)

17. P. Nistoreanu, A. Aluculesei, D. Avram, Information, 11 (8), 389 (2020)

18. W. Asante, E. Acheampong, E. Kyereh, B. Kyereh, Land Use Policy, 66, 374-381 (2017)

19. V. Moskalenko, I. Yevsieieva, International Economics Letters, 4 (2), 91-102 (2015)

20. T. King, M. Cole, J. Farber, G. Eisenbrand, D. Zabaras, E. Fox, J. Hill, Trends in Food Science \& Technology, 68, 160-175 (2017)

21. B. Pancino, E. Blasi, A. Rappoldt, S. Pascucci, L. Ruini, C. Ronchi, Agricultural and Food Economics, 7 (1), 1-10 (2019)

22. J. Jägermeyr, Frontiers in Sustainable Food Systems, 4, 35 (2020)

23. H. Seligman, S. Berkowitz, Annual Review of Public Health, 40, 319-337 (2019)

24. R. Weber, L. Bell, A. Watson, J. Petrlik, M. Paun, J. Vijgen, Environmental Pollution, 249, 703-715 (2019)

25. N. Georgescu-Roegen, Oxford Economic Papers, 12 (1), 1-40 (1960)

26. L. Klerkx, E. Jakku, P. Labarthe, NJAS-Wageningen Journal of Life Sciences, 90, 100315 (2019)

27. K. De Roest, P. Ferrari, K. Knickel, Journal of Rural Studies, 59, 222-231 (2018)

28. S. Baizakov, J. Forrest, N. Baizakov, Advances in Systems Science and Applications, 19 (2), 101-119 (2019)

29. T. Noszczyk, Human and Ecological Risk Assessment: An International Journal, 25 (6), 1377-1405 (2019)

30. B. Gardner, American agriculture in the twentieth century: How it flourished and what it cost (2009)

31. I. Darnhofer, S. Bellon, B. Dedieu, R. Milestad, Agronomy for sustainable development, 30 (3), 545-555 (2010)

32. G. Rausser, W. Strielkowski, D. Štreimikienè, Energy \& Environment, 29 (1), 131-146 (2018)

33. M. Sarker, M. Wu, G. Alam, M. Islam, International Journal of Agricultural Resources, Governance and Ecology, 15 (4), 323-337 (2019)

34. S. Hoekman, A. Broch, X. Liu, Renewable and Sustainable Energy Reviews, 81, 31403158 (2018) 